\title{
CORAZÓN COMO SÍMBOLO DE VULVA
}

\author{
Francisca Martín-Cano Abreu \\ Arqueóloga y Antropóloga, Zaragoza
}

https://doi.org/10.33676/EMUI_nomads.55.17

\begin{abstract}
Resumen.- Diferentes «símbolos de amor practicado por féminas»: amor propio (a sí misma: realiza sexo a solas); amor a otra persona en pareja: del mismo género (amor lésbico) o diferente (amor heterosexual); amor promiscuo [realiza sexo con varias personas, con total libertad y sin estereotipos sexuales: con práctica homosexual, heterosexual, bisexual, bien de forma simultánea (en trío, en grupo...), o diacrónica: una pareja tras otra; amor zoófilo... diseñados por La Autora.

Por un lado, como imitación de algunos ideomorfos de obras de arte de culturas prehistóricas y primitivas, tras decodificar su simbología metafórica -que los prehistoriadores académicos, interesados en descubrir el sentido oculto de obras de arte complejas, han considerado indescifrables en los cien años de Arqueología científica-; por otro lado, desafiando las interpretaciones androcéntricas de algunas figuras humanas y quiméricas.
\end{abstract}

\section{Heart as a symbol of vulva}

Abstract.- Different «symbols of love practiced by females»: self-love (to herself: she does sex alone); love to another person as a couple: of the same gender (lesbian love) or different (heterosexual love); promiscuous love [performs sex with several people, with total freedom and without sexual stereotypes: with homosexual, heterosexual, bisexual practice, either simultaneously (in trio, in group ...), or diachronic: one partner after another; love zoophile ... designed by the Author.

On the one hand, as an imitation of some ideomorphs of works of art from prehistoric and primitive cultures, after decoding their metaphorical symbolism - that academic prehistorians, interested in discovering the hidden meaning of complex works of art, have considered them indecipherable in the hundred years of Scientific archeology-; on the other hand, challenging the androcentric interpretations of some human and chimerical figures.

\section{Corazón como símbolo de vulva}

En febrero del 2004, una chica argentina llamada Carolina, me expresó: «Estoy buscando un símbolo que muestre el amor infinito o eterno». (Carolina, 2004).

Entonces le envié y publiqué unos dibujos -que había diseñado en 2003, para usar en mis investigaciones y libros de "Sexualidad femenina»-, en forma de «corazón vulvan». Lo hice como remedo de algunos ideomorfos en forma de "corazón»-presente en obras artísticas de la Prehistoria y de culturas primitivas [cuyo sentido metafórico como 
representación simbólica de la «vulva»/de los genitales femeninos había traducido de forma pionera (rechazando por tanto la interpretación generalizada academicista, que consideraba que representaba para aquellos remotos tiempos, el "órgano de la circulación de la sangre»)]-, y le añadí una parte central en la que explicitaba sin lugar a dudas su significado implícito.

Son algunos de los corazones representados en la Tabla 0. Muestran explícitamente: arriba las curvas de las posaderas, abajo el Monte de Venus con su vello púbico, en medio la entrada vaginal, capuchón y clítoris. Los corazones se hallan acompañados 0 solos... en representación de los diferentes actos de amor: entre dos féminas (lésbico en postura de tijera), de amor propio (autoestimulación con la mano o con dildo), de amor heterosexual (junto a falo masculino), de práctica cunnilingual (junto a cabeza animal con lengua fuera), de amor promiscuo en total libertad (corazón alado)...



Tabla 0. Imágenes que diseñé en 2003 (la autora), conformados como un corazón vulvar: arriba la imagen de las posaderas / el trasero femenino, en medio una abertura/entrada a la vagina como herida de la que fluye líquido (lubricación y líquido de la eyaculación del orgasmo) como remedo de obras de arte prehistóricas y primitivas que lo reflejan de forma metafórica/oculta

Respecto al corazón, me preguntaba en 2004: ¿̇a este "corazón» vulvar se refería originariamente la expresión coloquial de que «la mujer se mueve por el corazónı, es decir por sus pulsiones sexuales / por su manía sexual / por su ninfomanía / por el ardiente deseo de su ninfa (labios menores de su vulva) y clítoris, en vez de «moverse por la razón» / el cerebro, antes de que las represiones patriarcales y religiosas le quitaran la potencia sexual y el derecho a ser ninfomaníaca? (La Autora, 2016: 237).

Y fue la imagen de dos corazones unidos por la punta: Tabla 1: -que traduje reflejaría la postura de la tijera de dos féminas en oposición golpeándose/frotándose sus vulvas-, al que califiqué como «símbolo de amor infiniton, y al que aplico la reflexión de Juan Beltrán (2005): ya que 
realmente tiene forma de 8 acostado: A John Wallis, (...) debemos el símbolo del infinito.

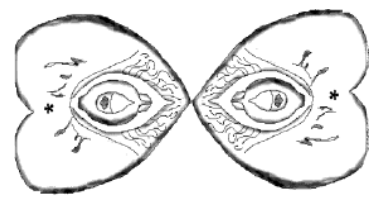

Tabla 1. Amor lésbico: dos corazones en oposición unidos por la punta conformando un ocho falentadores a féminas a practicar la postura de la tijera)

\section{Razón de que descubriera el sentido metafórico de variados ideomorfos}

La razón de que descubriera la relación entre el ideomorfo en forma de "corazón» con la "ivulva» [y el de muchos otros motivos, bien de la naturaleza, o geométricos $u$ otros más complejos presentes en obras de arte primigenias: "triángulo», «flon», «quimera», «ninfa... que aparecen desde inicios del nacimiento del arte, -cuyas explicaciones más profundas pueden ampliar en (La Autora, 2017: 216-283)]-, se debió:

- En primer lugar a varios conocimientos: como mi formación en Psicología, mi entrenamiento en resolver metáforas (sólo quienes hayan sido entrenados en el patrón de pensamiento metafórico, como: poetas, psicólogos, mitólogos... pueden decodificarlas) y a que recopilé múltiples y dispersas informaciones multidisciplinares (de: Arqueología, Mitología, Religión, Astronomía, Antropología, Etnología...) de muchas culturas. Gracias a todos ellos me hicieron entrever con muchas evidencias que el arte primigenio no representaría exclusivamente hechos reales, sino que encerraría un sentido metafórico más complejo.

Por ejemplo, uno de los primeros ideomorfos del que deduje su significación oculta de «vulva» fue el de la "fflor». Es obvio que existe paralelismo entre ambos términos, ya que son los "órganos sexuales», en un caso de las plantas y en otro de las féminas. Hecho que en occidente aún en el siglo XXI conserva tal identificación metafórica (y se sustituye un término por otro), y aún se manifiesta cuando a las chicas se les horada la vulva por primera vez: ha sido «desflorada».

Y también explica tal analogía el hecho de que tras la revolución patriarcal, la palabra «ramera» se aplicase a las futuras esposas que para conseguir la dote o para las que no conseguían mantenedor, les permitían ejercer la prostitución: poner su «flor/vulva» al servicio del que le pagaba; pero «ramera» término originario que definía las prácticas secretas nocturnas orgiásticas femeninas de la autoestimulación de su «flor/vulva» y que participaban en procesiones llevando flores. 
Otro ideomorfo que deduje era símbolo de "rvulva/de sexo femenino» fue el urombo» o el del «triángulo», hasta el punto de que la posición de las manos configurando un rombo, ha sido usado durante años en las manifestaciones reivindicativas por las feministas. Incluso existen representaciones escultóricas que les debieron servir de modelos, como ilustra el que dibuja las manos de la madre encima de su nenita: Tabla 2, de un monolito de la cultura de San Agustín, que se desarrolló en Colombia entre los años 550 adne al 1300 dne y en la que se rendía culto a la Gran Diosa Madre.

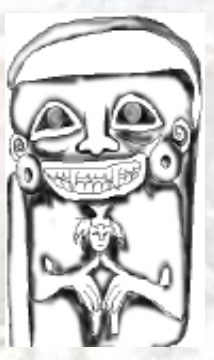

Tábla 2. Rombo o triángulo alusivo a género femenino / a genitales de fémina / a vulva

- En segundo lugar, descubrí el sentido oculto de ideomorfos complejos, gracias a mis fuertes convicciones feministas -que me habían motivado a investigar desde una visión interdisciplinar y acumular desde 1999, muchos miles de obras artísticas de culturas de la Prehistoria y de los periodos más arcaicos del arte primigenio de otras-.

Lo que me llevó a descubrir que el género de tales representaciones primigenias, tanto figurativas (representadas de forma real o estilizadas, con o sin mamas) como antropozoomorfas (efigies quiméricas, sin existencia real, reflejo por tanto de complejas ideas metafóricas), eran representación exclusiva de Lo Femenino.

Idea que ha sido explicitada por muchos honestos investigadores, pero que ha sido ignorada por prehistoriadores academicistas, debido a que su androcentrismo les ha hecho dar interpretaciones sesgadas a muchas obras de arte primigenias "asexuadas» o "femeninas», que definen como umasculinasi). Y con esas falsificaciones androcéntricas, han cerrado las vías para que cualquier/a investigador/a hallase que un «ideomorfo» podría representar una «vulva».

Esas obras de arte figurativas (naturalistas o estilizadas), zoomorfas o quiméricas muestran la sexualidad natural de la mujer: tanto sus "prácticas primarias» (orgiásticas: autoestimulación a solas, o relación sexual acompañada de otra compañera), como "secundarias»" (embarazada, dando a luz, de mamar...). Y hecho que ha pasado totalmente desapercibido en los últimos cientos de años para 
prehistoriadores académicos, condicionados en la visión sesgada heteropatriarcal.

Y el hecho de que las «obras de arte figurativas» mostrasen la sexualidad natural femenina, me dio la ocasión de generalizar que tal usexualidad natural femenina» estaría asimismo representada en los «ideomorfos abstractosı.

Por todas estas razones me fue posible hallar el sentido oculto de obras de arte complejas, mientras ha pasado totalmente desapercibido para prehistoriadores académicos, ya que ninguno ha recibido formación respecto a los antecedentes citados; y ello seguirá siendo causa incluso de que incluso las nuevas generaciones de prehistoriadores puedan entender mis explicaciones, dado que siguen siendo condicionados en las mismas falsedades y construcciones androcéntricas de hace 100 años.

\section{Corazón solos, metáforas de autoestimulación de vulvas, con o sin dildos}

Ahora, añado a los dibujos simbólicos de corazones que envié a Carolina, otros corazones presentes en obras de arte reales que encierran idéntica metáfora: aluden a vulvas.

En la Prehistoria y en culturas primitivas los corazones como símbolos de vulvas aparecen en obras de arte, Tabla 3: bien solos o delante de la mano de una jóvena, o acompañando a una fémina, o delante de una fémina, o aparece como abdomen en una representación antropomorfa femenina, acompañado con espirales como si fueran los brazos y las piernas (babeo), o el corazón se presenta delante de la mano de una ninfa o de una esfinge con alas (como quimeras no son seres reales, aluden a ideas metafóricas complejas); además muestro figuras femeninas que reflejan de manera bien explícita que está autoestimulándose con mano dirigida a su vulva (y por tanto con ellas se estaría alentando la automasturbación femenil de forma obvia), y en algún ejemplo, la vulva a la que se dirige su mano tiene forma de corazón...

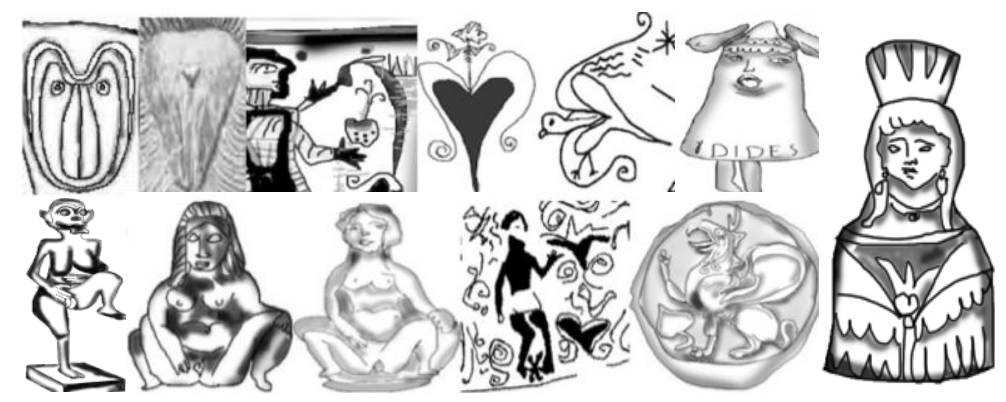


Tabla 3. Corazón en obras de arte, bien solo o delante de una ninfa/jóvena orgiasta, o forma parte como abdomen de una figura antropomorfa femenina, o está en lugar de la vulva de una figura real femenina, -que codifica con sentido metafórico y con sentido obvio- la instrucción modélica a las vicarias de la Diosa para que practicasen la autoestimulación de su vulva, con la finalidad de conseguir llegar al orgasmo y correrse y en la esperanza de propiciar «mágicamente» que la Diosa las imitase y enviase la Fertilidad /la Lluvia (necesaria para la abundancia de alimentos vegetales): se creían ser «Hacedoras mágicas de la lluvia»

Tanto con las representaciones artísticas de orgiastas que se automasturban, como con los rituales reales secretos orgiásticos, que eran llevados a cabo por las jóvenas/ninfas vicarias que les hacían llegar al orgasmo y correrse/lanzar líquidos esperaban propiciar "mágicamente» que la Diosa las imitase y enviase la Fertilidad/Lluvia (necesaria para la abundancia de alimentos vegetales). Y es por ello que se creían ser «Hacedoras mágicas de la lluvia».

Mostramos en Tabla 4, dos obras de arte de La India y de un cultura mexica, que evidencian expresamente esa urazón mágica», ya que lo llevan implícitamente: En ambos casos las vicarias se creen ser "Hacedoras de lluvia»; en el primer caso: la vicaria de la Diosa Kali tiene una mano dirigida hacia abajo (su vulva suelta líquidos/está eyaculando/corriéndose durante el orgasmo) y la otra la dirige hacia arriba (la Flor/Vulva de la Diosa con espirales/caracoles, símbolo de líquido): está expresando su esperanza mágica de que la práctica orgiástica en su vulva que la hace correrse, provocará mágicamente que la Diosa la imite y la hará enviar la Fertilidad/la Lluvia.

En el caso de la escultura mexica, la vicaria sostiene un dildo y de su vulva sale un chorro lleno de vida que atraviesa una especie de máquina y desemboca en una cabeza con lengua fuera en espiral en lo alto, con lo que está expresando lo mismo: la esperanza de que el líquido de su eyaculación actuará como la fuerza de una máquina que llegará hasta la Diosa en lo alto y afectará a su Vulva para que envíe la Fertilidad/Lluvia.
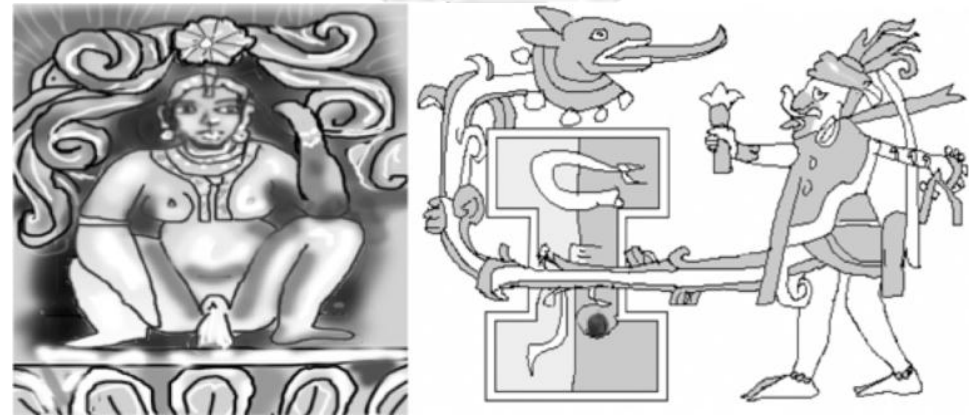
Tabla 4: razón mágica de las prácticas orgiásticas de vicarias de la Diosa Madre Natualeza,expresada en estas dos obras de arte de La India y de cultura mochica: Sus líquidos de la eyaculación acturán mágicamente en la Vulva de la Diosa en lo alto y la hará expulsar la Fertilidad/la Lluvia

Han sido realizadas en lugares y épocas muy alejadas entre sí en el tiempo y en el espacio, señal de que compartieron las mismas ideas, mitos y ritos alegóricos desde el Paleolítico matriarcal. Todas portan similar instrucción y simbolizarían el amor propio: eran alentadoras de las prácticas sexuales orgiásticas (antes de que sobreviniese la revolución patriarcal, prohibiesen a la mujer dirigir los cultos sagrados, y su actividad sexual se redujera drásticamente para subordinarla, con la obligación de que se conservaran puras y decentes, al servicio de un esposo y reducidas a la maternidad).

También diseñé para mis investigaciones y libros un dibujo simbólico de corazón a punto de ser perforado por una orgía / báculo / flecha de Venus: Tabla 5. (En este caso, la orgía es una escultura hermafrodita húngara de Starcevo, Endröd-Szjóskereszt, del Neolítico, aproximadamente del año 5000 adne).

Y desde luego lo diseñé como símbolo de amor propio, y reflejo de las autoestimulaciones que las mitólogas ancestrales aconsejarían a las vicarias que imitasen, para conseguir que se «corrieran» y soltasen ríos de fluidos (y que entonces estaría unido a la squirt "eyaculación» que acompaña al orgasmo clitoriano, y que hoy día la mayoría de las mujeres occidentales ya no conseguimos, al habérsenos atrofiado las glándulas parauretrales responsables de ello -debido a que nuestras madres nos han impedido "ser cochinas" /satisfacer nuestro derecho biológico al placer sexual que aparece desde que nacemos, aunque sigamos usando de forma incorrecta la expresión de «corrernos» para aludir al éxtasis del orgasmo-). Pero también podría reflejar una escena de amor a una fémina, bien por parte de un compañero o de una compañera que sería el que usaría la orgía/el falo artificial-.

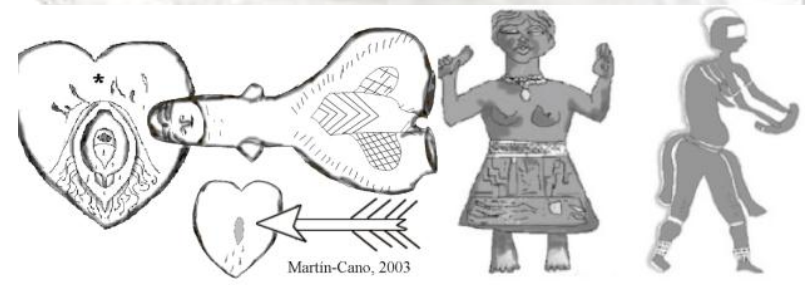

Tabla 5. Corazón como símbolo de: amor propio con báculo / orgía (y de corazón atravesado por flecha) y Ninfas orgiastas/jóvenas con orgía en mano/báculo (sugiriendo a vicarias de la Diosa que lo usaran en sus prácticas orgiásticas para que se autoestimularan la ninfa/labios 
menores de la vulva: porque como «Hacedoras mágicas de la lluvia» así creían que la provocarían

Lo acompañé de otro corazón al que se dirige una flecha, que identifiqué con la Sagittae Veneri "Flecha de Venus», -que se convirtió en época de transición al patriarcado en un motivo analógico de una flecha de amor tirado por Eros/Cupido (mito nacido tras la revolución patriarcal).

Pero reproduciría y alentaría ya las prácticas sexuales de época patriarcal del coito y del amor heterosexual: que consideraba que era primordial que la hiriente saeta de Eros / flecha de Cupido (pene masculino), entrase en un "corazón» vulvar como punto de tiro y lo traspasase con fuerza; con ello haría concebir a la dueña/mujer hasta que pariera a su hijo. Porque iqué creen que significa el mito de que Eros/Cupido cuando tiraba una flecha (falo) hacía enamorar a una jóvena elegida tras entrar en su corazón (vulva), sino referirse a la fecundación, tras haberle traspasado esa facultad: su arma Sagittae Veneris, su Madre Afrodita? Y Diosa Afrodita considerada en principio que poseía ambos géneros (era por tanto Hermafrodita) y no necesitaba ser fecundada, ya que era Ella la que se creía que causaba la Fertilidad/Lluvia de toda la Naturaleza y la Fecundación de humanos -cuando se desconocía el poder fecundador del varón-.

A continuación muestro dos obras de arte de féminas orgiastas que portan orgías/báculos/dildos, con la sugerencia a vicarias de la Diosa a que las remedaran en prácticas orgiásticas/autoestimulativas con dildos hasta conseguir el estallido del orgasmo y su eyaculación simultánea, durante los ritos sagrados para propiciarla: en la creencia de que conseguirían así que mágicamente que la Vulva de la Diosa Hermafrodita las imitaría y enviaría la Fertilidad / la Lluvia.

\section{Corazones unidos, símbolos de uniones sexuales lésbicas}

En Tabla 6: mostramos imágenes artísticas prepatriarcales de corazones acompañados de otro corazón, uno encima del otro lque decodificamos reflejaría la monta lésbica). Tal postura es idéntica al que reflejaría la amazona resbalando exageradamente de una yegua, o montada sobre una cochina, o la quimera con alas (ninfa) montada sobre otra, o la cabeza femenina sobre otra... 


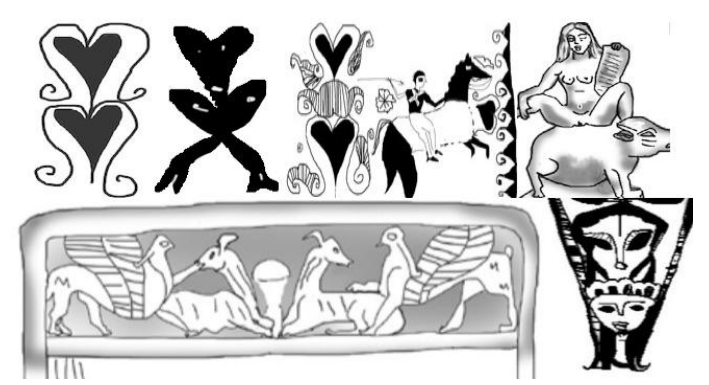

Tabla 6. Amor lésbico: dos corazones, uno encima del otro, o una fémina sobre un animal (yegua, cochina, vaca.../ siendo el animal representativo metafórico de fémina), o un animal sobre otro, o una cabeza femenina triangular sobre otra... En todos los casos representaciones metafóricas alentadoras a féminas a la monta lésbica: como amazona sobre su yegua, o como boyera/bollera sobre su bovis «vaca», o porqueriza sobre su cochina, o ninfa sobre su cierva/sierva...

O bien los corazones que aparecen en escenas artísticas prepatriarcales podían aparecer, Tabla 7: en oposición unidos por la punta (configurando un ocho) o unidos por la base, y que en ambos casos harían alusión metafórica a dos órganos sexuales enfrentados por la región pélvica (y reflejaría la postura de la tijera) simplificados como X (equis), o de la "Cruz» usados para alentar al acto lésbico entre dos mujeres.

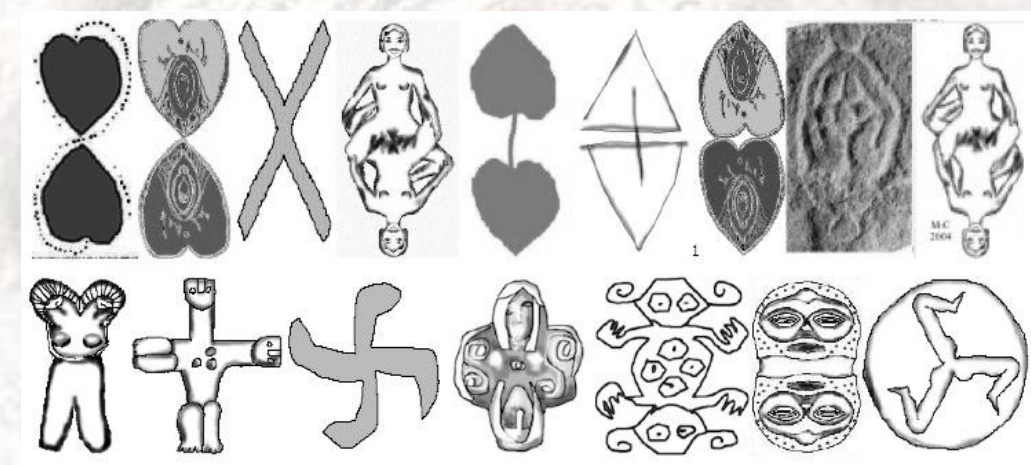

Tabla 7. Amor lésbico: dos corazones en oposición unidos por la punta o unidos por la base (o triángulos o cabezas femeninas...), con o sin falo (alentadores a féminas a practicar la postura de la tijera)

Tal postura en la Prehistoria matriarcal y en culturas primitivas maternales codificaba el modelo que habían de practicar las Sacerdotisas de la Diosa en sus rituales orgiásticos lésbicos/«dos amigas de corazón» para que combatiesen/se frotasen y chocasen las vulvas en la postura de la tijera. (La Autora, 2016: 230).

Idéntica idea encierran las imágenes artísticas de dos corazones en oposición unidos por la base, o los dos triángulos unidos por la base (con 
o sin falo artificial entre ellas); o se representaba en figuraciones humanas duales... de dos féminas en oposición unidas por la base (patriarcalizados por la postura de los bustos de los reyes en oposición, de las barajas), o dos cabezas en oposición unidas por la base, bicéfalas... como las esculturas de féminas estrechamente enlazadas en tal postura de Laussel (Francia); las de Ecuador (cultura de Valdivia, del año 2250 al 1320 adne) cuyas cabezas son fálicas, lo que denotan su hermafroditismo; la en forma de "Cruz») de Chipre (de Lapitos de hace 4.000 años); asimismo, la pintura del símbolo vasco Lauburu (de lau "cuatro» y buru "cabeza»), cruz encomada vasca, variante de la esvástica o cruz gamada, reflejaría tal acto en la postura lésbica de tijera, frotándose los sexos en el centro); las dos cabezas en oposición unidas por lá base: de Argentina, de Chile y de Costa de Marfil; mientras que el triskel que aparece en la moneda fenicia de Sicilia, en forma de tres piernas unidas por las ingles (quizás aludiría a un acto lésbico entre tres mujeres).

Además las imágenes de cuerpo de féminas en forma de corazón bicéfalo de Anatolia del IIIer milenio adne de Tabla 8: reflejarían similar postura lésbica (con dos cuellos y dos cabezas fálicas con glande), llamada de forma androcéntrica por prehistoriadores como ídolos (para enmascarar el género femenino, representación de la Diosa Hermafrodita, en cuyo honor sus vicarias practicaban actos orgiásticos para propiciarla).

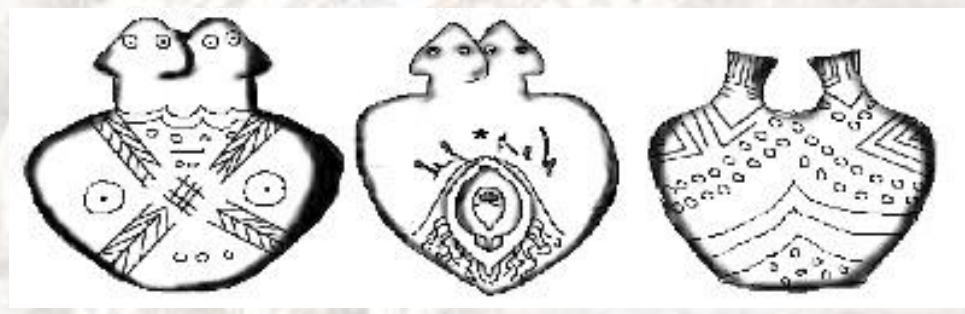

Tabla 8. Dos ídolos femeninos abstractos bicéfalos de Anatolia con cuerpo en forma de corazón (la primera decorada con espigas en forma de " $X \backslash \Downarrow$ y dos cabezas fálicas con glande, que aludiría a pareja lésbica en postura sexual de tijera, o a la Dualidad Divina femenina / Dualidad Ancestral Hermafrodita / Andrógina). La «X»: figura simplificada que imita tal postura. Y en medio, un dibujo mío, recreación como símbolo alusivo del amor lésbico

Uno de Kültepe / Kül-Tepé, ex-Kanesh / Kadesh / Kanish / Ganish, cerca de Kara-Uyuk, en Capadocia y otro de Cay Kenar. La primera escultura -que tiene el cuerpo en forma de corazón- está decorada con mamas y espigas formando una "X» y la remata dos cabezas fálicas (aludiría tanto al hermafrodismo de la Diosa: a su Androginia y a su Virginidad: se creía que poseía los dos sexos y concebía sin necesidad de ser fecundada por el Principio masculino, como al acto que habrían de 
practicar las vicarias de la Diosa: frotar sus dos corazones vulvares para hacerlo uno, y así creerían que afectaría mágicamente al Corazón/Vulva de la Diosa para que enviase la Fertilidad, que haría a las semillas germinar, a los difuntos resucitar...).

Y conocemos otras figuras bicéfalas similares realizadas en la Prehistoria de: Francia, Italia, Rusia, Rumania, Yugoslavia, Mesopotamia, Anatolia, Chipre, Las Cícladas, y existen otros de América, África y Oceanía.

\section{Animales con lengua fuera, símbolo de cunnilingus}

También de época prepatriarcal nuestras ancestras nos han legado imágenes artísticas de cabezas de animales con la lengua fuera: a punto de lamer/devorar/comer..., bien a otro ser que se halla cerca, o las posaderas de otro animal. Por eso realicé un símbolo de una perra con lengua fuera junto a un corazón: como símbolo de amor zoófilo. Por lo que incluiría el amor entre dos especies distintas: una mujer se deja hacer el cunnilingus por un animal (amor zoófilo).

Posteriormente me di cuenta de que -aparte de que nuestras ancestras pudieran dejarse practicar esos actos sexuales orales con animales reales (ejemplificado en las fiestas sagradas Misias: Razón de las ceremonias licenciosas de mujeres con perras (La Autora: 2013: 72-74)-, en realidad en principio sus obras de arte primigenias de animales o de quimeras con lengua fuera, como de figuras femeninas reproducirían de forma metafórica su invitación simbólica a las vicarias de la Diosa para que practicaran actos de sexo oral, para que unas actuasen como activas «perras lamedoras» o "cochinas hozadoras» (hicieran "cochinadas») y por tanto sugeridoras de que actuasen como esos hacían: lamieran y hozaran. Y otras como pasivas "conejas», «peces», «ninfas», «quimeras sirenas», "corazones»... («vulvas») y se dejasen comer/devorar/chupar [sus razones complejas las hemos profundizado en La Autora, Tomo 3, 2016: 165, 171, 253, 433, 439, 442, 525,...].

Mostramos varias escenas metafóricas de obras de arte prehistóricas con la invitación modélica al cunnilingus lésbico/sexo oral entre vicarias de la Diosa en Tabla 9: tanto de animales con lengua fuera (representación de vicaria activa) dirigida a corazones (vulva de vicaria pasiva), o dirigidas a figuras antropozoomorfas o fémina con cabeza de corazón (vulvas de vicarias pasivas)... Las dos últimas escenas con imágenes más complejas serían alentadoras de la práctica de sexo oral a dos vicarias en la postura del «69». Ampliamos en La Autora, 2016: 443 y 446). 


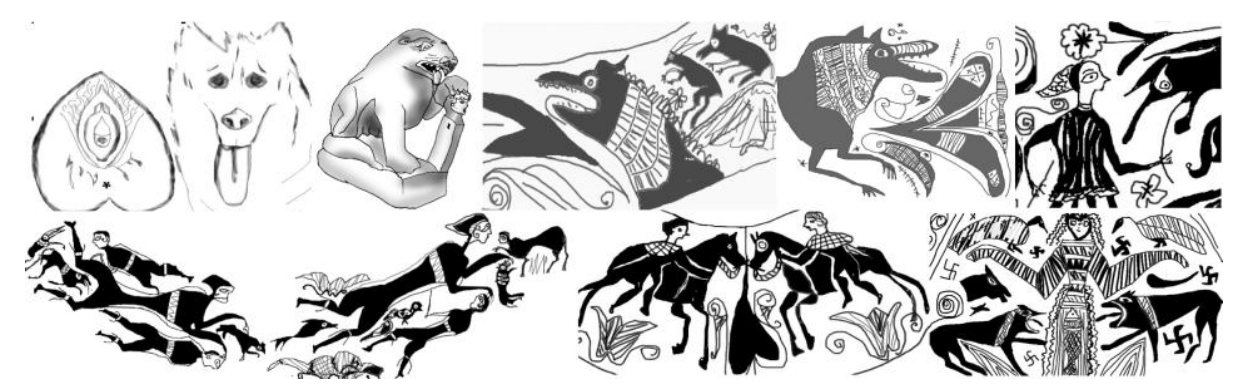

Tabla 9. Lenguas saliendo de bocas femeninas o animalísticas dirigidas a corazones, como símbolo de Amor lésbico e invitación a la práctica del cunilingo, bien de activa a pasiva o de dos féminas en postura del 69

Hay un poema de Safo que manifestaría tal identificación. Así, cuando dice: Viniste, hiciste bien, te anhelaba a mi lado,/ a ti, que enfriaste mi corazón ardiente de deseo (García Gual, 2996: 69), está claro que se refiere a que la amada satisfizo su deseo sexual, con el cunnilingus que enfrió su «vulva caliente» / su ardiente "corazón», hasta hacerla estallar en el orgasmo y la eyaculación que acompañaría.

\section{Otros símbolos de amor femenino promiscuo...}

Y existen otras representaciones artísticas legadas de época ancestral de símbolos de amor promiscuo femenino, sin los estereotipos propios del patriarcado, como las reflejadas en Tabla 10: el corazón alado, otro de los dibujos simbólicos que envié a Carolina: símbolo de la total libertad femenina y de sus prácticas sexuales con una pareja tras otra de cualquier género de forma diacrónica.

Acompaña un grupo de tres cabezas-corazones adosados en pilar africano de Nigeria coronado del pueblo Idoma, símbolo de promiscuidad/de prácticas sexuales de féminas vinculadas de forma simultánea; y existen numerosos ideomorfos en la Península lbérica de corazones embutidos unos en otros en línea con similar metáfora orgiástica-lésbica, o adosados como tréboles.

En la escultura de origen tasmanio de la zona de Marecageuse en la costa sudoeste de Nueva Guinea, Melanesia, se muestra la promiscuidad femenina con actos sexuales formando trío con dos varones simultáneamente. realiza felación a un compañero, mientras otro la penetra. 


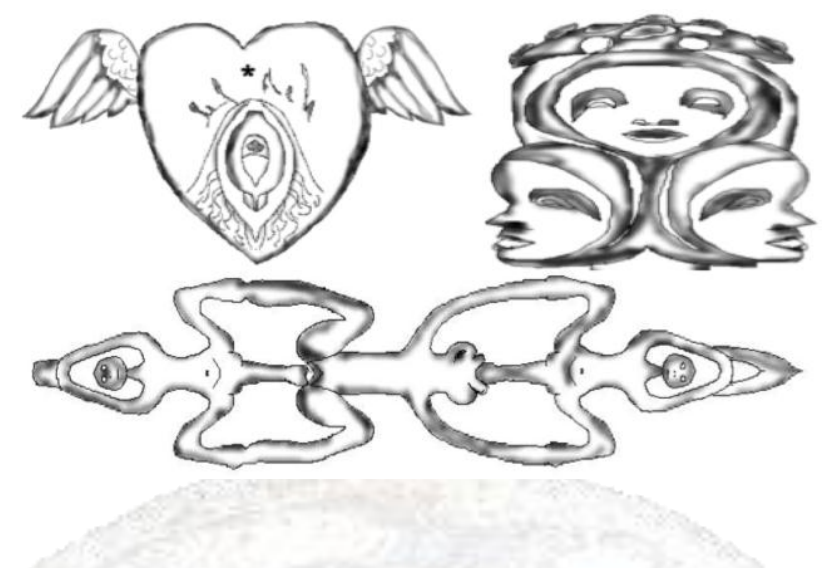

Tabla 10. Tres caras-corazones unidos: símbolo de promiscuidad de féminas en trío; corazón alado: símbolo de libertad sexual femenina; escultura de fémina que hace felación a varón mientras otro la penetra: símbolo de promiscuidad de fémina con dos varones/de poliandria...

Otro de los dibujo simbólicos con corazones que hice y envié a Carolina fue el símbolo de amor heterosexual, reflejo del coito, Tabla 11: corazón júnto con pene. (Práctica que sería también realizada desde el Paleolítico, ya que la especie humana no desapareció, aunque no existen representaciones figurativas hasta la Edad del Bronce).



Tabla 12. Amor heterosexual: corazón junto con pene reflej0 de del coito heterosexual

Tras de las revolución patriarcal iniciada al final del Neolítico, los varones negaron a las mujeres el derecho al trabajo para autoabastecerse, e institucionalizaron, por un lado: la vinculación mujer-varón en el matrimonio legal heterosexual monógamo, por el que el esposo, se comprometía al sustento de su pareja y el de sus hijos, a cambio de su dedicación sexual en exclusiva; y por otro lado: institucionalizaron el comercio carnal, mediante la prostitución legal femenina, para que la mujer que no conseguía esposo, aceptase en burdeles poner su vulva al servicio del varón que la pagase.

Y las mujeres hubieron de poner sus vulvas, bien al servicio sexual y carnal del esposo sustentador en su papel exclusivo de procreadora, 
continuamente embarazada, o bien del que le pagara el acceso carnal. Todas por tanto, sometidas y subordinadas al placer masculino.

Y desde entonces fueron obligadas a practicar el coito como principal práctica sexual que se les permitía practicar.

Condicionándose a la par en los varones, a actuar meramente como empotradores para conseguir su orgasmo fecundador, sin preocuparse de que su compañera consiguiera su éxtasis.

Y las mujeres desde entonces quedaron sin derecho a gozar de su sexualidad genética, libre, lésbica promiscua... que habían gozado durante toda la Préhistoria matriarcal.

\section{Bibliografía}

"CAROLINA" (2004): Email enviado al correo de mi grupo culturaarcaicaowner@yahoogroups.com, el 24 de febrero. "Carolina" <carolina@rmunoz.com.ar>

BELTRÁN, Juan. (2005): «A John Wallis, miembro fundador de la Royal Society de Londres y editor de obras de Arquímedes del XVII, debemos el símbolo del infinito que usamos actualmente, ese 8 acostado-»r. usuarios.lycos.es/juanbeltran/id377.htm

GARCÍA GUAL, Carlos. (1996): Antología de la poesía lírica griega. Alianza Madrid.

La Autora, F. (1999a): Las claves del Arte y la Religión Prehistórica. Ponencia al XXV Congreso Nacional de Arqueología, Valencia, Diputació de València, pp. 217-222, ISBN 84-7795-202-7.

- (1999b): Significados metafóricos de glifos gallegos y de otros lugares... Ponencia al Congreso Internacional de Arte Rupestre Europea, Actas en DVD, Concello de Vigo, Dto. Patrimonio Histórico, Depósito Legal VG$503 / 2001$.

- (1999C): Situaciones estelares de los 22 días de fiesta fijados hace 5.300 años. Ponencia a las VII Jornadas Astronómicas del Planetari de Castelló, Mz. (Actas en prensa). La Autora.webcindario.com/ca.9calendario.htm

- (2000): Del matriarcado al patriarcado. Humanidades en la Red, Universidad de Almería, Ed. Fernando Muñoz. Portal Mujer Palabra, Ed. M. Renyé. mujerpalabra.net/pensamiento/ La Autora /matriarcadoapatriarcado.htm

- (2001): Las fechas de cada uno de los 22 días de fiesta arcaicos y sus precisas situaciones estelares... Ponencia al XXVII Congreso Nacional de Arqueología, Inst. Estudios Altoaragoneses, Diputación de Huesca. Bolskan, No 18, pp. 265-282, ISSN 0214-4999. 
- (2002): De las flechas que herían a Diosas, a luchas entre Divinidades (hacían el amor) y producían la lluvia, a las flechas traspasadas por Diosas a sus hijos que herían de amor a humanos (les hacían fluir lubricante y semen): $\mathrm{m}$ La Autora.webcindario.com/diosas.amor.html

- (2004): Símbolos de amor propio, de amor infinito (lésbico) y de amor entre dos (homo, hetero y zoófilo). El Club de Ensayos y Trabajos: Buenas Tareas. Portal Indepedent Academia Educación.

- (2004b): Orgías ancestrales con bastones sagrados (1) y (2). Revista de Sexología, Número 7 Octubre del 2004 y Número 8 Abril del 2005, Ed. Miguel Arroyo. galeon.com/culturaarcaica/orgiabaston.htm

- (201 1): Vulyas y clítoris/Genita FEM. Lista de Distribución Feministas de laneta.apc.org/

- (2012): Sexualidad femenina en diversas culturas. De ninfómanas a decentes. Tomo 1. Chiado Ed., 296 págs., ISBN: 9789896976200. chiadoeditorial.es/libreria/sexualidad-femenina-en-diversas-culturastomo-i

- (2013): Sexualidad femenina en ritos, obras de arte y mitos. Del mundo de la Diosa a la sociedad patriarcal. Tomo 2. Chiado Ed., 347 págs., ISBN: 978-989-51-0219-8. chiadoeditorial.es/libreria/sexualidad-femenina-enritos-obras-de-arte-y-mitos-del-mundo-de-la-diosa-a-la-sociedadpatriarcal-tomo-2

- (2016): Arqueología Feminista Ibérica. Tomo 3. Prólogo de la Artista Visual: Pilar Catalán Lázaro. Letras de Autor Ed., 653 pgs., ISBN: 978-8416538-67-6. www.chiadoeditorial.es/libreria/sexualidad-femenina-endiversas-culturas-tomo-i

- (2017): Sexualidad femenina en el tercer milenio. Tomo 4. Mujeres recuperan su hipersexualidad. Letras de Autor Ed., 269 pgs., ISBN: 978-8417101-73-2.

letrasdeautor.trckacbm.com/url/ver/23342242//391222/3drlm3UvmCIWY acbf9l16vJuYhWd 1Rvj5BmaXx8m 